\title{
THE USE AND MAINTENANCE OF HORSES IN THE ASPECT OF NATURAL TRAINING METHODS
}

\author{
${ }^{1}$ Institute of Animal Science and Fisheries, Siedlce University of Natural Sciences and Humanities, \\ Poland \\ ${ }^{2}$ Department of Horse Breeding and Use, University of Life Sciences in Lublin, Poland
}

\begin{abstract}
As a result of evolution, humanity transitioned from a nomadic to a sedentary way of life, from hunting and gathering to crop production and animal husbandry. Domestication involved capturing wild horses and adapting them to the conditions in which they were raised by humans. This resulted in a change in the treatment of horses and the perception of their emotional needs. The focus shifted to building relationships with the horse, understanding it, and treating it as a rational being. Currently, horses are seen as one of the most intelligent animals 'cooperating' with people. In this study, 62 horses at four equestrian centres were examined. The horses included mares, stallions and geldings between the ages of 3 and 26 years, belonging to eight breeds: Arabian, Malopolski, Hucul, Polish Half-Bred, Silesian, Polish Coldblood, Shetland pony, and Haflinger. The analysis of forms of horse training indicated that all centres used classical training methods for $100 \%$ of their horses. The trainers declared interest in natural methods, but as support for classical training. Natural methods of working with horses were applied at centres 2 and 3, where horses were ridden both for recreation and for sport. This type of training was not observed at centre 1 , where horses were used only for recreational riding, or at centre 4, which dealt mainly in breeding and training of race horses. Horses at centre 3 and most of those at centre 2 took part in in Parelli's Seven Games, Join-Up, and desensitization to unknown objects, and imprinting of foals was practiced. This indicates that horse trainers are currently applying natural methods, but are not completely giving up classical training. A study was carried out to investigate the approach of contemporary horse breeders to forms of housing and use with respect to their interest in foal imprinting, natural horsemanship, Join-Up, and desensitization to unknown objects.
\end{abstract}

Key words: horse, natural training methods, imprinting, desensitizing.

\section{INTRODUCTION}

The evolution of equids began 60 million years ago, with the appearance of an animal the size of a fox (Haller 1997). Living in the steppes, horses evolved into ungulates, developed their mental and physical traits, and adapted to existence in a variety of environmental conditions (Fedorski 2003). The odd-toed ungulate ancestor of the Equidae was Pliohippus, which lived about 10 million years ago. In its limb structure and dentition it resembled the modern horse, whose exterior and interior characteristics were continually influenced by man. This led to the development of a number of principles for handling horses, aimed

Corresponding author: Agata Danielewicz, Institute of Animal Science and Fisheries, Siedlce University of Natural Sciences and Humanities, Bolesława Prusa 14, 08-110 Siedlce, Poland, e-mail: agata.danielewicz@uph.edu.pl 
at ppropriate responses to training tasks (Dudziak 2012; Zeitler-Feicht 2014). However, this classical method did not provide a prescription for forms of conduct in all training processes. In their search for solutions in problematic situations, especially where previous solutions had failed, people focused on building a psychological relationship with the animal. They began to analyse and attempt to understand its behaviour and perceived it as an intelligent being (Szymczak 2004; Christensen et al. 2006; Gołąb 2017).Observations of the horse's natural instincts are used to understand its psyche and behaviour, to communicate with it, look after its welfare, and in consequence to achieve harmony and complete trust (Szymczak 2004; Wilczyńska et al. 2017).

An important aspect of equestrianism is human-horse cooperation, which is based on mutual trust, respect, and striving to reach agreement without the use of coercion or punishment (Jackson 2003). The growing interest in various forms of natural horsemanship reflects a change in peoples' attitude towards animals, from instrumental to empathic. The reason may lie in growing awareness of the sensitivity and subjectivity of animals. As a result, enormous changes have taken place in the way people perceive them (Birke 2008; Żebrowska et al. 2013; Jodkowska et al. 2016).

Horse communication primarily consists of body language - a language specific to horses which expresses their emotions and transmits information (Gołąb 2017). Horses express emotions using a variety of gestures and postures, enabling interpretation, the formation of relationships in the herd and of social bonds, and the establishment of a hierarchy. The horse also interprets the body language of people; it has an excellent ability to sense human emotions and mood, such as anxiety or fear. Even when people attempt to mask their feelings, the horse will recognize them correctly. In addition to body language, horses also use vocal (acoustic) communication, primarily when optical signals, i.e. body language, are misunderstood (Gołąb 2017).

Classical horse training, used since the dawn of time, developed canons of conduct that achieved the desired training effects in most horses, but these methods proved inadequate for certain tasks. It is these problematic situations and misunderstanding of the animal's behaviour that have led to interest in natural horsemanship. The natural horsemanship system is based on analysis of the psyche and behaviour of horses, care for their welfare, and common sense. The word horse-man-ship means horse and man, walking in harmony together, but with the horse always first (Dudziak 2012). One of the contemporary representatives of natural horsemanship is the American horse trainer Monty Roberts, who runs the Equestrian Academy in California. He uses natural training methods and is famous for his Join-Up technique and the language Equus, which he believes horses can use to communicate among themselves and with people. Join-Up is a method that aims to create a bond and build trust between human and horse using the horse language Equus. This process is based on the horse's acceptance and unconstrained performance of exercises (Bayley 2006). A good trainer can get a horse to do what it requires of him; a great trainer will induce the horse to work voluntarily. The horse should be raised without coercion or violence, and the animal should have freedom of choice (Roberts 2004).

The Parelli Natural Horsemanship programme is based on the Seven Games: the Friendly Game, the Porcupine Game, the Yo-Yo Game, the Circling Game, the Sideways Game, and the Squeeze Game. By guiding the horse through this programme, we will teach itself- 
-confidence and gain its trust (Bayley, 2006). Pat Parelli has also developed a proper way to handle horses. This is known as the $4 \times \mathrm{F}$ method: fair, friendly, firm, and fast. These words suggest how we should respond to and work with the horse (Diacont 2001).

Imprinting is a special form of behavioural tie between animal and human (Fraser 2010). The term 'foal imprint training' was coined by the American veterinarian Robert Miller. Imprinting is contact between a human and a foal at birth, which is why foals should be accustomed to the human being immediately after birth (Gohl 2001). The optimal moment to carry out imprinting, when it will be most effective, is up to an hour after birth (Miller and Lamb 2005; Mille, 2007). It should only be carried out if it is certain that the delivery has gone well, and it must be ensured that the bond between the mother and the foal will not be disturbed. The imprinting period is a kind of 'desensitizing' of the horse, eliminating opposition to the human and building respect for and trust in him (Roberts 2004; Łojek and Łojek 2015).

Desensitization is an effective way to eliminate horses' fear of new objects. When a horse overcomes its fear of one object, it is easier for it to overcome fear of the next (Hill 2015, 2016). Desensitization aims to accustom the animal to the touch, sound, and smell of previously unfamiliar objects or circumstances. It also increases the horse's tolerance to stress (Wilk and Janczarek 2014).

A study was carried out to investigate the approach of contemporary horse breeders to forms of housing and use with respect to their interest in foal imprinting, natural horsemanship, Join-Up, and desensitization to unknown objects.

\section{MATERIAL AND METHODS}

In 2019 an analysis was performed of the living conditions and training of 62 horses located at four centres. The data for all horses was analysed individually, and the trainers' interest in classical and natural training methods was established in detail. The relationships between the training systems and the housing systems and use of the horses were examined.

Centre 1 kept four mares and six geldings, including seven Malopolski horses, two Silesian geldings and one Polish Half-Bred mare, the oldest of the horses. The youngest was a 5-year-old Malopolski gelding. Centre 2 had 11 horses, including one Haflinger stallion, four mares two Malopolski, one Arabian, and one Polish Coldblood, and six geldings-three representing the Malopolski breed, two Shetland ponies and one Polish Coldblood. The oldest were mares, on average 16.25 years old (the oldest was a 19-year-old Polish Coldblood). The stallion was 14 years old, and the average age of the geldings was 12.83 . The youngest was a 6 -year-old Shetland pony. Ten horses were kept at centre 3-six mares, two Malopolski and four Hucul, and four geldings, including three Malopolski and one Hucul. The average age of the horses was 10.33 years in mares and 11.25 in geldings, with the oldest horse belonging to the Malopolski breed. Centre 4 had 31 horses - four Arabian stallions, 22 Arabian mares, and five geldings four Silesian and one Malopolski. The average age of all horses was 7.71 years; the youngest were mares (average age 6.1 years), followed by four Silesian geldings (9.75), while the oldest were Arabian breeding stallions (13.5 years). 
Breakdown according to sex, breed, age, housing systems, time spent outdoors, and use of horses at each centre, as well as the training methods used, are presented in charts. As an example, Fig. 1 shows training to desensitize the horse to unfamiliar objects.

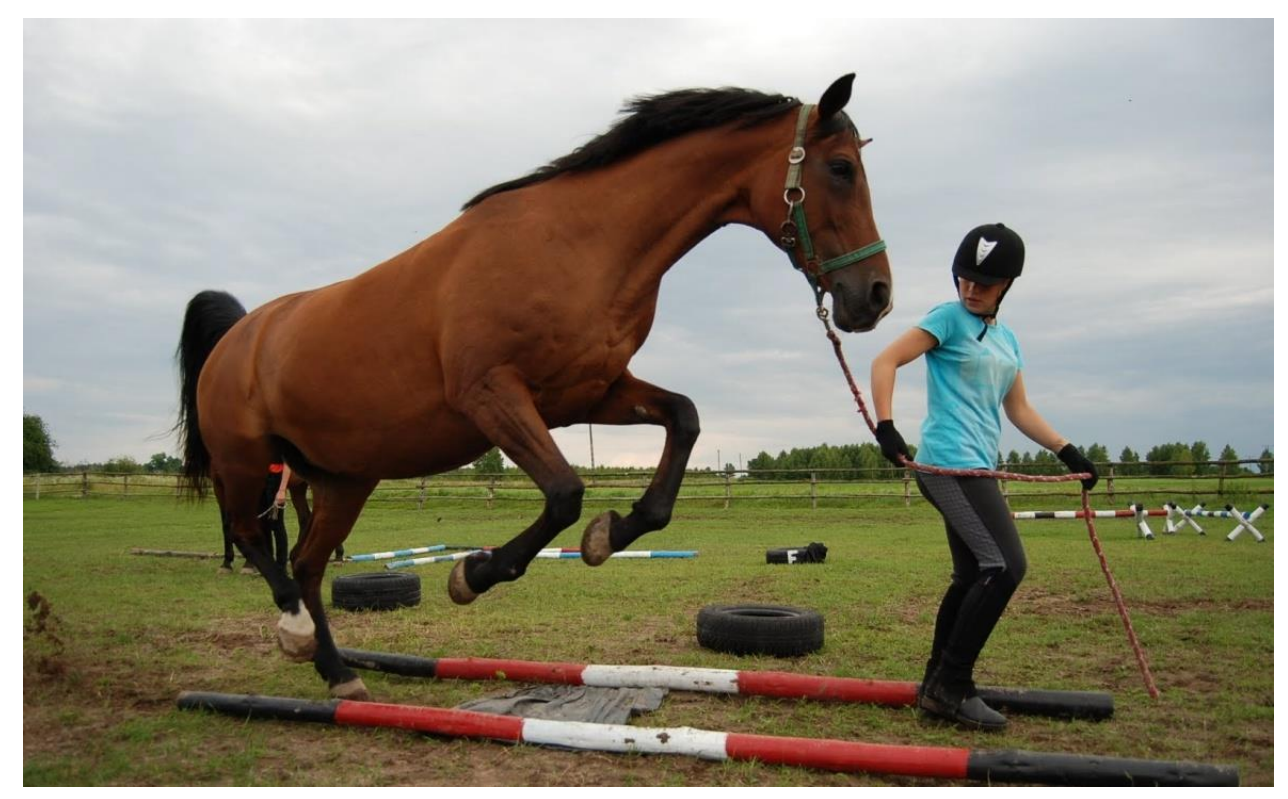

Fig. 1.Desensitizing to an unfamiliar object - rustling foil Source: authors' archives.

\section{RESULTS AND DISCUSSION}

At centre 1, all horses were kept in box stalls andspent 4 to 7 hours a day in the paddock. Nine horses were used for recreational riding, while the two Silesian geldings were used as draught horses. Seven of the animals worked 1-2 days a week, and three individuals worked 3-4 days a week. Two of the mares were used for breeding. All horses were imprinted except for the draught horses, which had been purchased. Desensitization was applied every day, through controlled familiarization of horses with new objects. Lungeing was carried out several times a week for each horse. The horses' first contact with a saddle and rider took place at the age of 3.5years, except for draught horses, whose first draught work began at the age of 4 years. All of the horses took on their first rider at the age of 4 years.

At centre 2, the horses were housed in a stable with boxes and spent over 12 hours a day in the paddock, except for the stallion, which stayed in the paddock for 8-11 hours. All horses were used for recreational riding, and seven were used for sport. One mare and one gelding of the Polish Coldblood breed worked as draught horses, and one mare was used therapeutically. The stallion was used for breeding. Work and training took place 3-4 times per week, except for the Arabian mare, which was used 1-2 times a week. All horses underwent imprinting, desensitization and lungeing. One mare did not participate in Join-Up training or Parelli's Seven Games. Contact with a saddle and rider began at the age of 3 years, or in the case of Polish Coldbloods, at the age of 2. Similarly, Polish Coldblood horses took on their first rider when they were 3 years old and the other horses a year later. 
Centre 3 used a 'free-range' system, which meant that the horses used the paddock for more than 12 hours a day and could choose whether to be in the stable or the pasture; they usually chose the pasture. All horses were used for recreational riding, and eight were used for sport. All mares were used for breeding. Training of most horses took place 5-7 days a week, except for one Malopolski mare, which was used 3-4 days a week. Eight horses were imprinted, all underwent desensitization, and Join-Up and Parelli's Seven Games were used. Contact with a saddle and rider was initiated at the age of 3.5-4 years. They took on their first rider between the ages of 3 and 5 years, on average of 4.15 .

At centre 4, the horses were kept in a stable with boxes, with17 mares and 5 geldings released into the paddock for 4-7 hours a day. The remaining 9 Arabian horses (5 mares trained for racing and 4 elite stallions) were not paddocked due to their use forracing and intensive daily training. Elite stallions were used for breeding and brought into the horse walker for 30 minutes of training every day. Most of the mares 5 years old and older were used for breeding, and the rest were used for racing - five Arabian mares, trained under saddle 5-7 days a week. Four Silesian geldings and one Malopolski gelding worked as draught horses 3-4 times a week. Only five of the 31 horses were imprinted after birth, and the draught horses were additionally desensitized and lunged. All horses had their first riding or draught experience at the age of 3 years.

Figure 2 presents data on the gender breakdown at each centre. The largest group of horses comprised mares, with 36 of 62 individuals (58\%), and the fewest horses were stallions $(8 \%)$, present at only two of the centres.

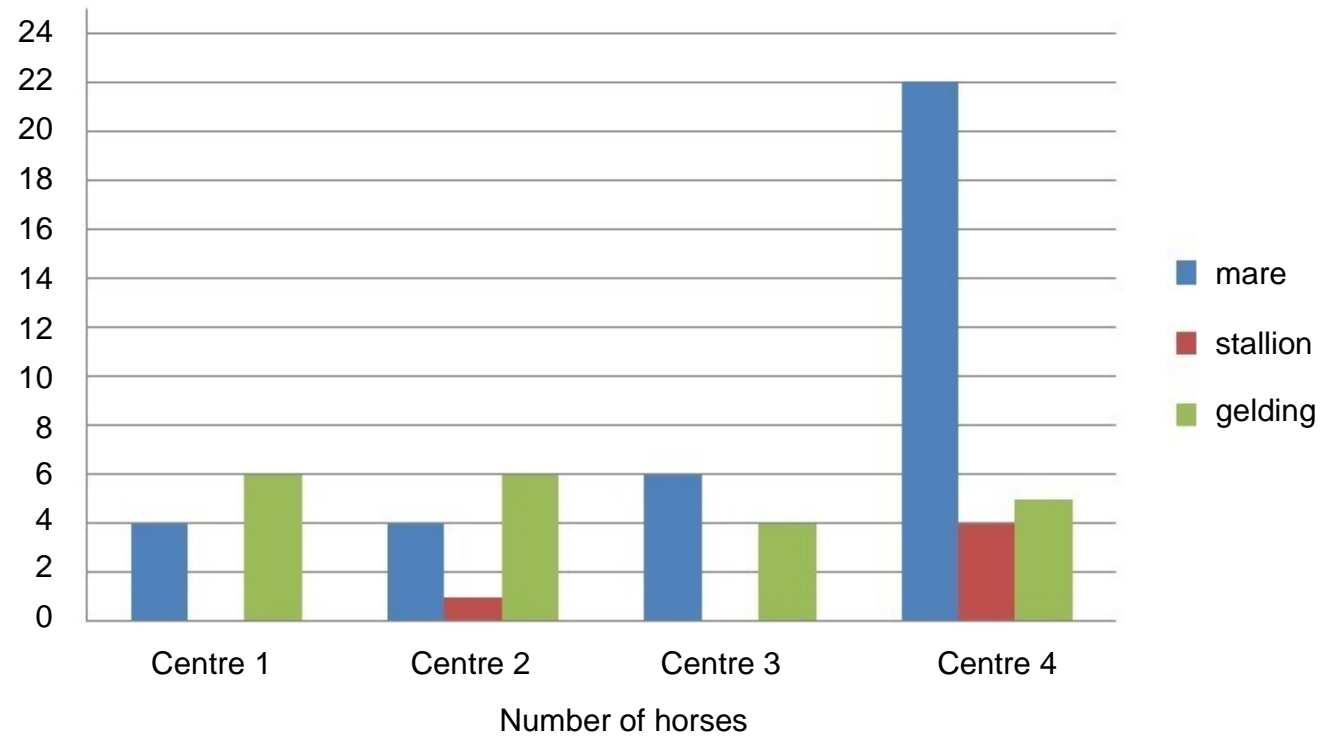

Fig. 2. Sex of horses

Figure 3 presents the breakdown of breeds at each centre. The dominant breed in the study was Arabian (27 horses). The Malopolski breed constituted a large group (18 horses). This is a popular breed at typical recreational centres in Poland. The Polish Half-bred and Haflinger breeds occurred sporadically. 


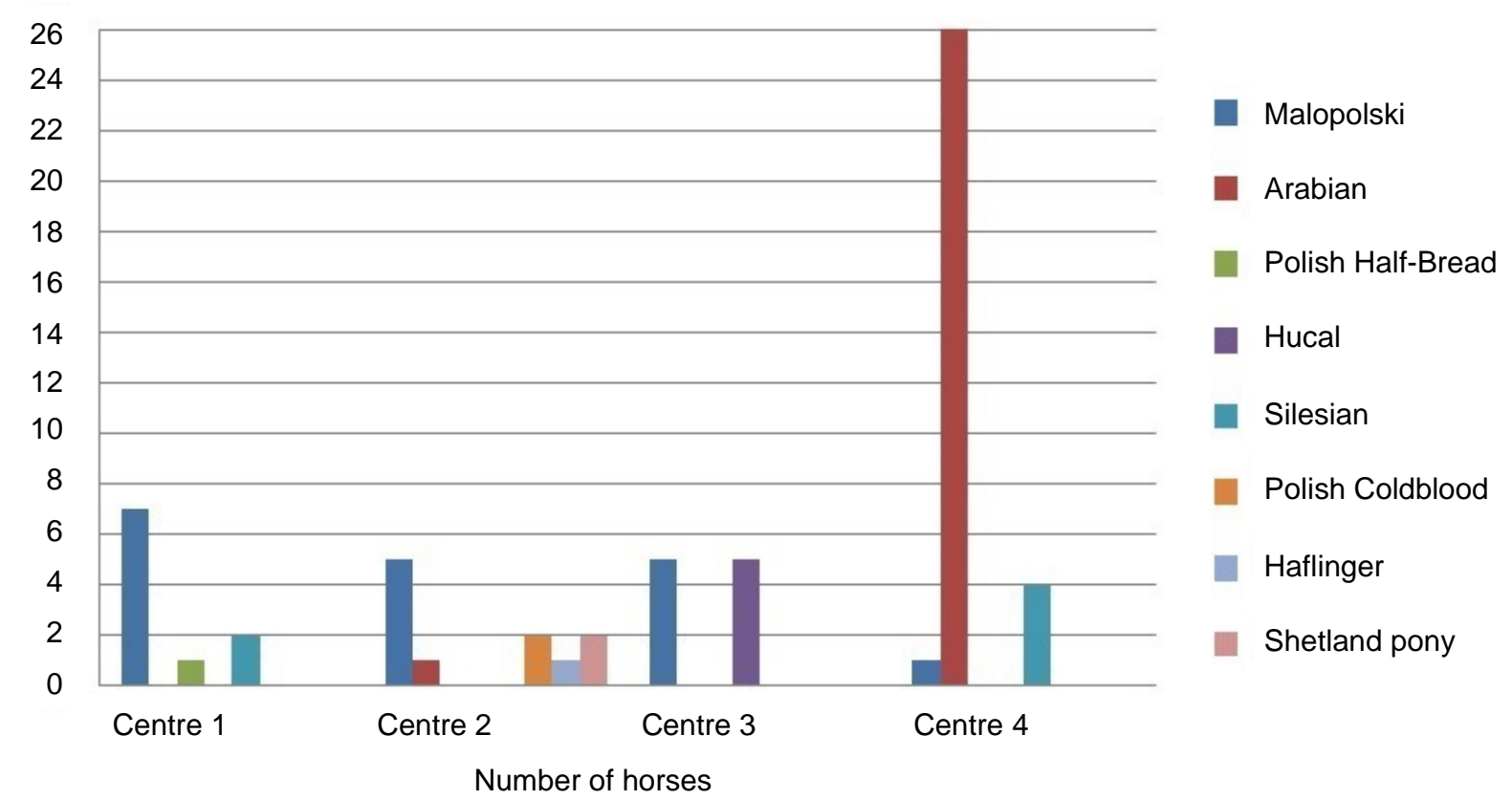

Fig. 3. Breeds of horses

Figure 4 presents the age breakdown of horses at each centre, which was varied. The most numerous were 5-, 6- and 12-year-old horses (7), and the youngest were 3-year-old mares.

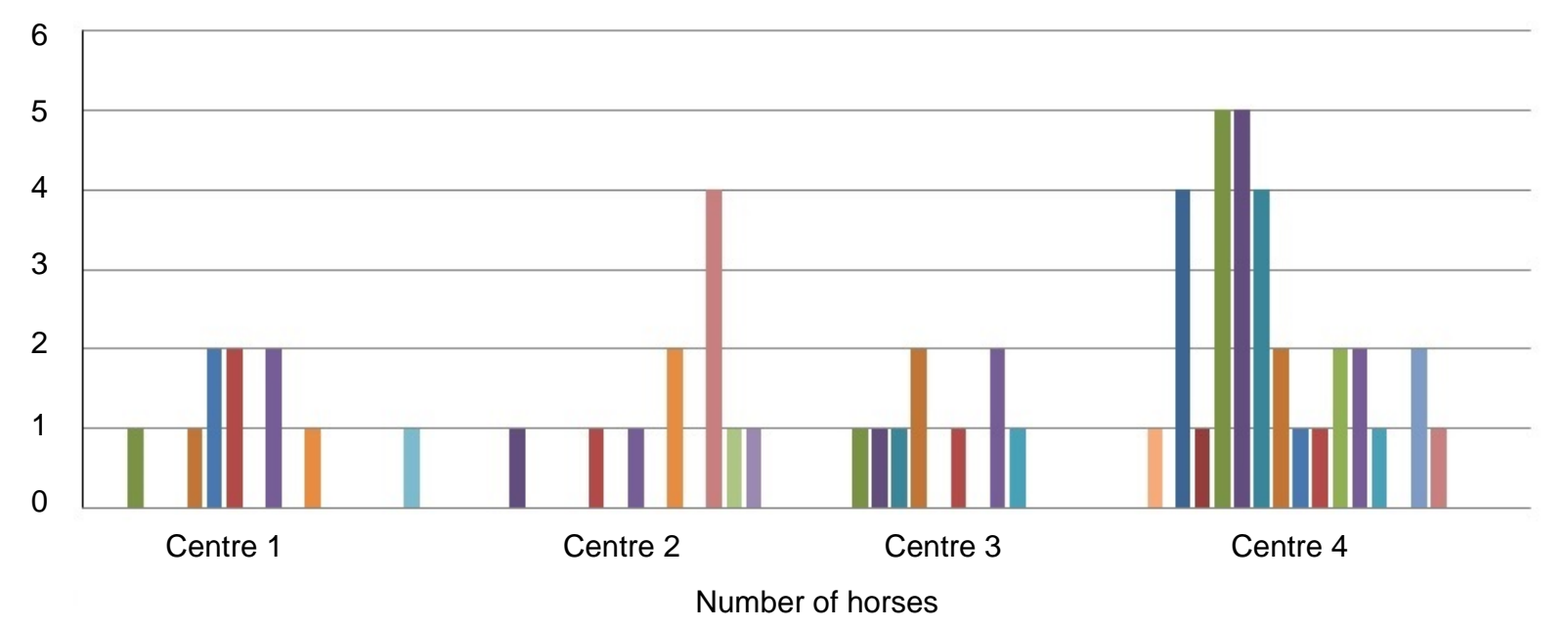

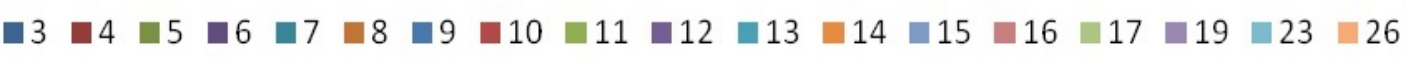

Fig. 4. Age of horses in years

Figure 5 presents the housing systems. The majority of horses $(52 ; 83.8 \%)$ were kept in a stable with boxes, while only $10(16.2 \%)$ were kept in a 'free-range' system, with access to the entire stable and pasture. The horses in this stable represented two breeds, Malopolski and Hucul. There was an established hierarchy in the herd, allowing the breeders to choose this form of housing, which is beneficial for the animals' psyche. 


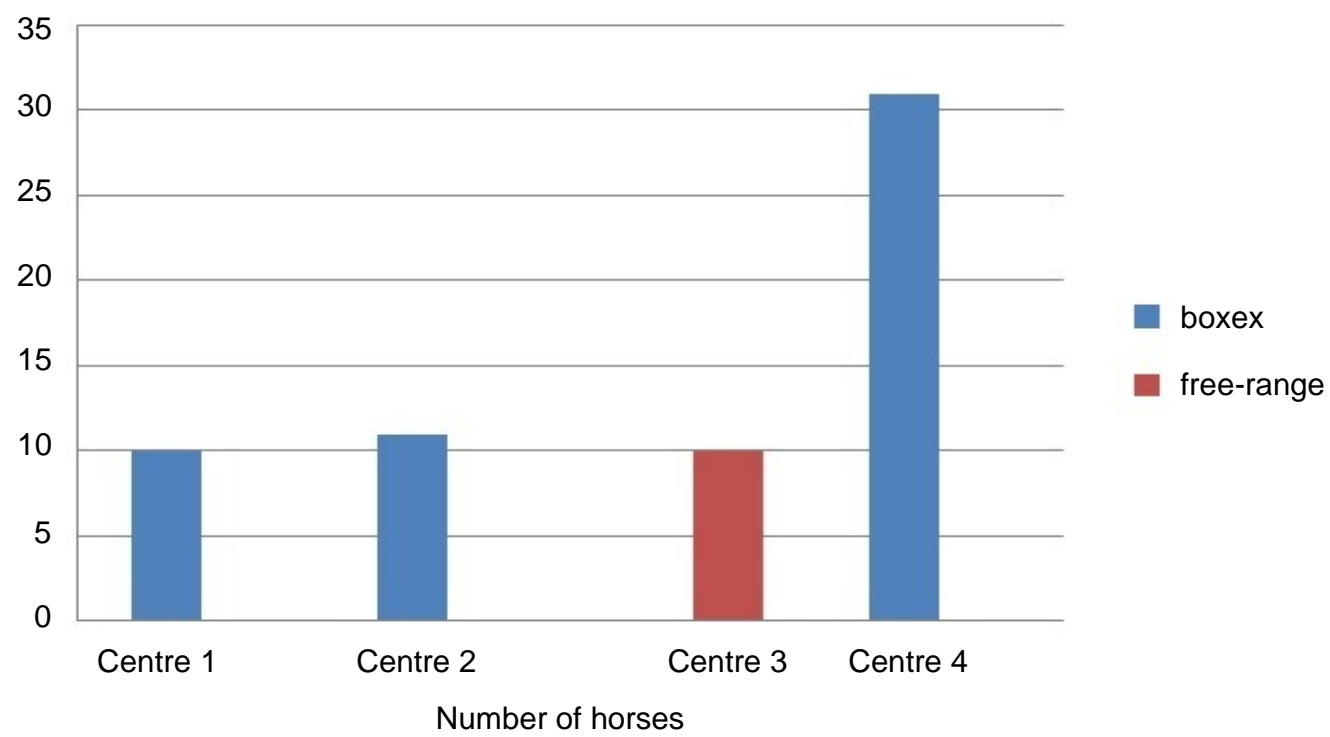

Fig. 5. Horse housing systems

Figure 6 shows how much time the horses spent outside, in the paddock or pasture, depending on the season. The most common time range was 4-7 hours a day (32 horses; $51.6 \%)$. Only one stallion spent 8-11 hours a day outside.

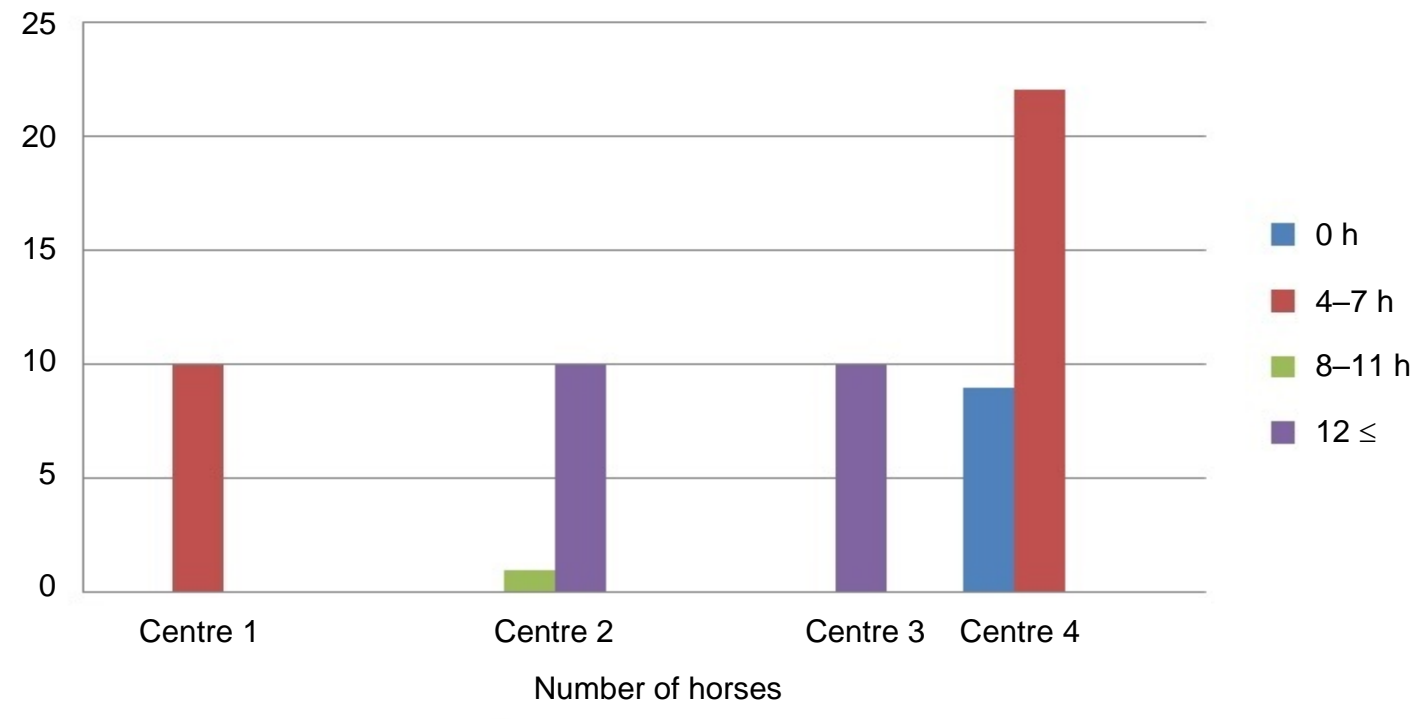

Fig. 6. Time horses spent outside (paddock/pasture)

Figure 7 shows how horses were used at each centre. Use for breeding was the most common (30 horses; 48.4\%), led by centre 4, with 17 Arabian mares and four Arabian stallions. In addition, six mares were used for breeding at centre 2. Only at centre 2 was a Haflinger stallion was used for natural mating. Riding was the most common use: 26 horses (42\%) for recreation (centres 1, 2 and 3 ) and sport racing (centre 4). Hippotherapy was the least common use of the horses. 


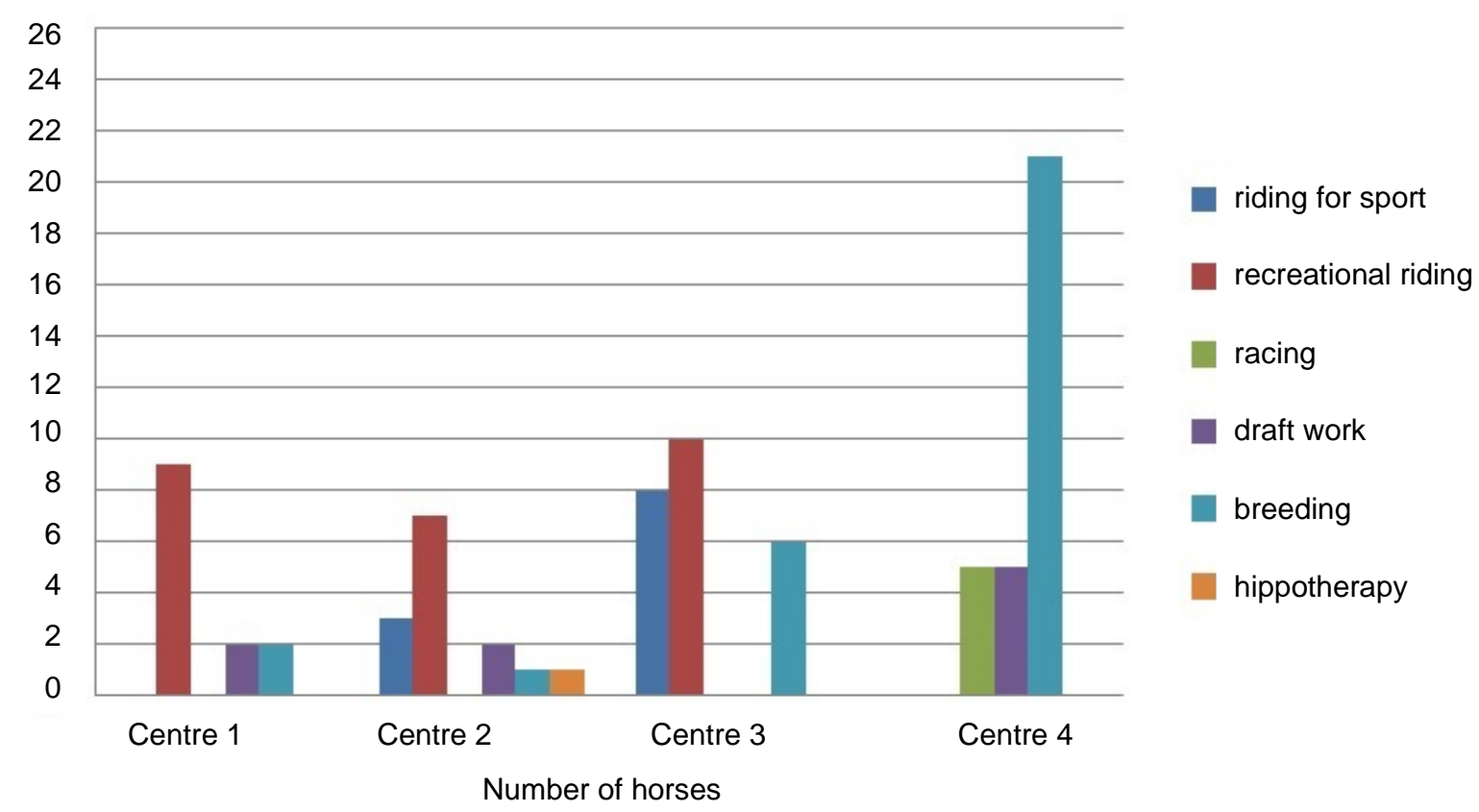

Fig. 7. Use of horses

Figure 8 shows the rate of use of imprinting, which slightly more than half of the horses were subjected to (32 horses; $51.6 \%$ ). At recreational centres, imprinting took place immediately after birth, while at centre 4 an individual system similar to imprinting was developed. Because there were relatively few caretakers (grooms) and too many mares giving birth at about the same time, foals were tamed during routine care and grooming. Foals were touched on various parts of the body during daily handling, feeding, and cleaning of the mares.

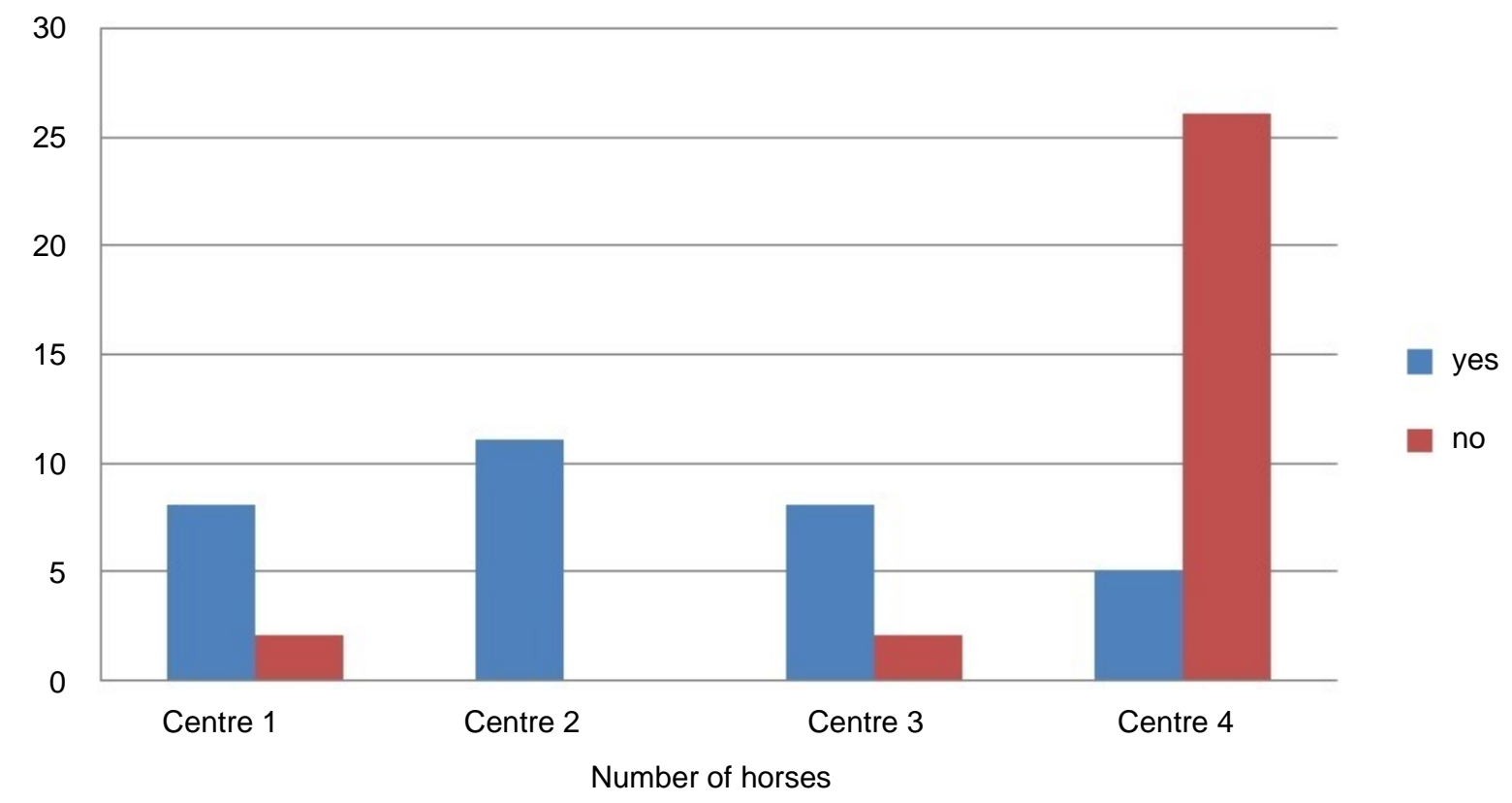

Fig. 8. Natural methods - imprinting 
Figure 9 shows the rate of use of desensitization. Most horses were desensitized (36 horses; 58\%). This method helped the horses to become familiar with new objects, thus eliminating their fear of them. Twenty-six horses (42\%) were not desensitized. The majority of horses for which this method was not used were horses at the stud. Desensitization is also shown in Photo 1, which shows training to desensitize and suppress negative behaviour in a mare that has been shown rustling black foil and offered direct contact with it. As a result of desensitization, after several sessions the horse accepted and carried out the command to walk calmly on the foil and even to stop and stand still on it.

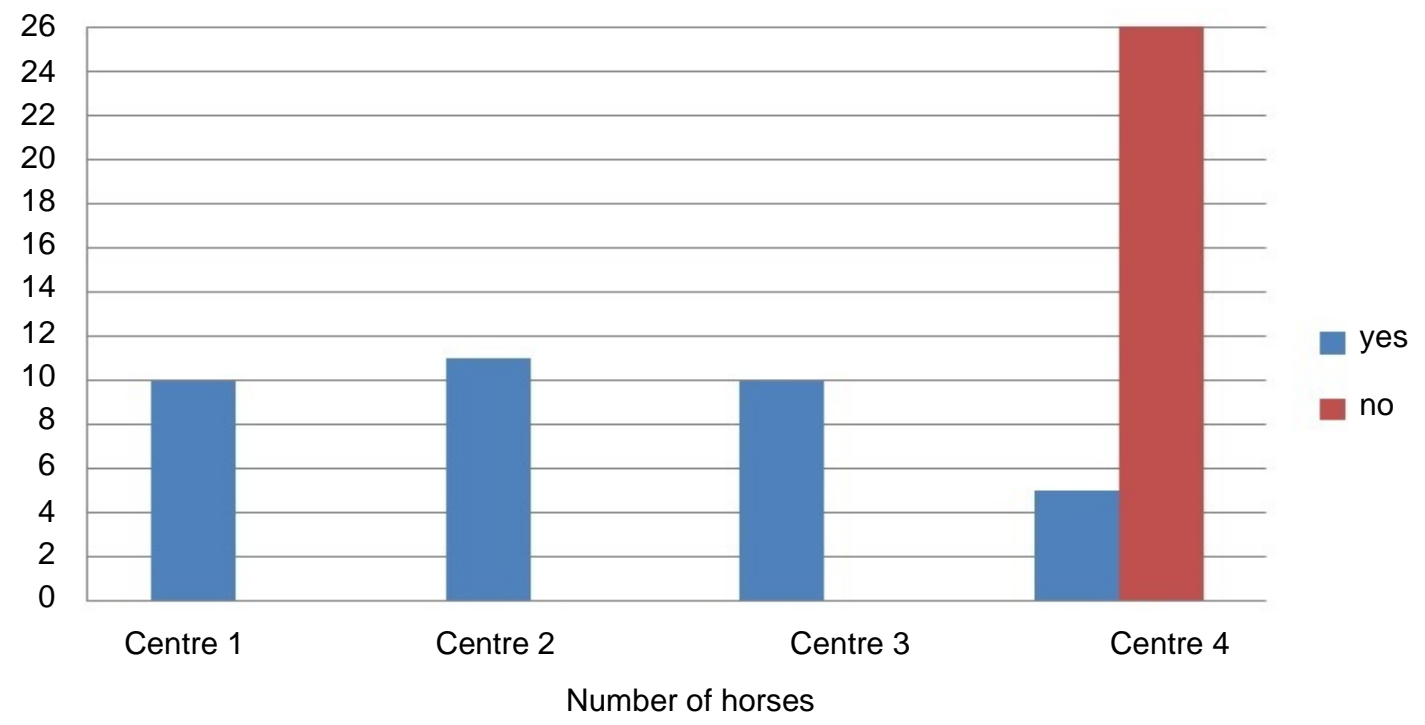

Fig. 9. Natural methods - desensitizing

Figure 10 presents the methods of work with horses used at each centre. The most common classical method was lungeing, which was used at three centres. The natural methods used included the Join-Up method (20 horses; 32.2\%) and Parelli's Seven Games (20 horses).

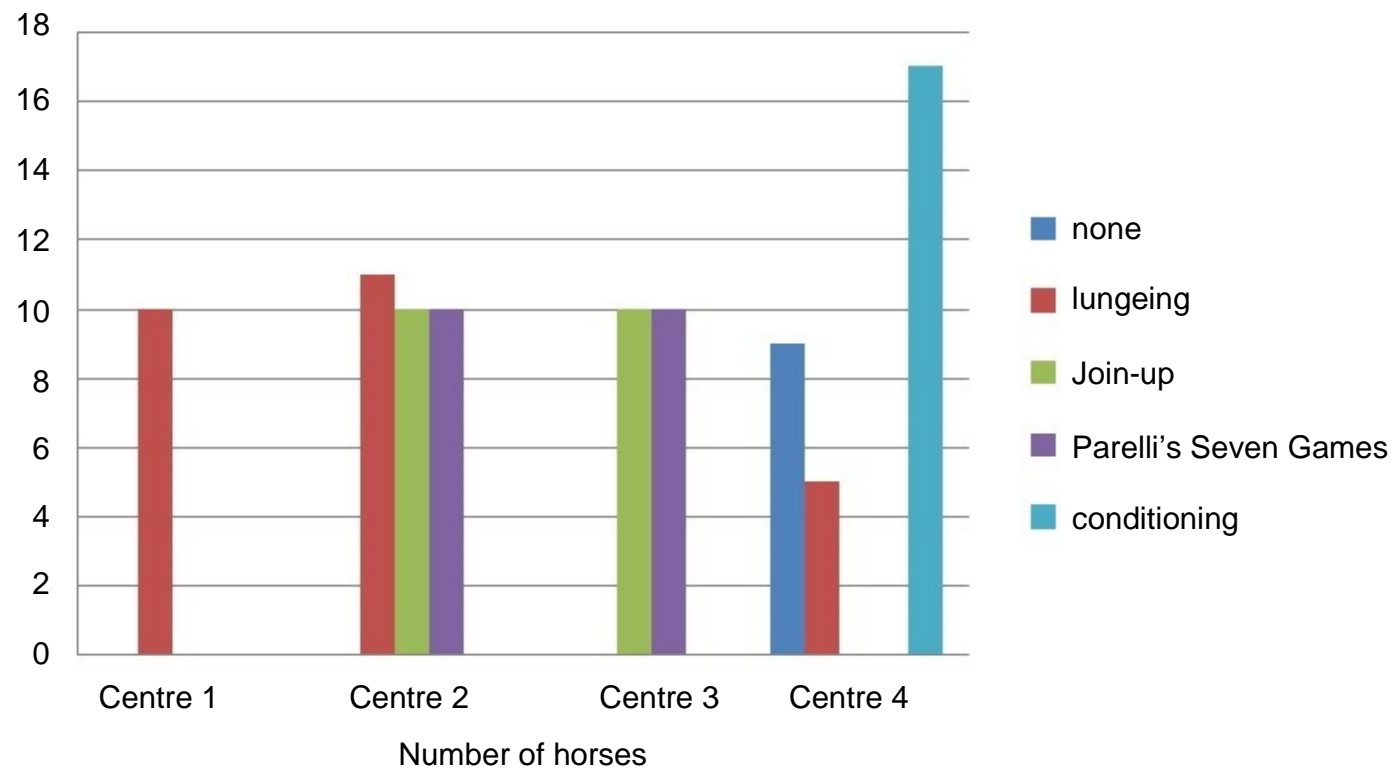

Fig. 10. Training methods 


\section{CONCLUSIONS}

The analysis of forms of horse training indicated that classical training methods were used for all horses at all centres. The trainers declared interest in natural methods, but as support for classical training. Natural methods of working with horses were used at centres 2 and 3 , where they were used for recreational riding as well as sport, while this type of training was not found at centre 1, where horses were used only for recreational riding, or at centre 4, which mainly bred and trained race horses. Horses at centre 3 and most horses at centre 2 took part in Parelli's Seven Games, Join-Up, and desensitization to unknown objects, and foals were imprinted immediately after birth. This demonstrates the growing interest in natural methods among horse trainers, although they are not able to completely abandon classical training.

\section{REFERENCES}

Bayley L. 2006. Nowoczesny trening konia. Warszawa, Muza. [in Polish].

Birke L. 2008. Talking about Horses: Control and Freedom in the World of Natural Horsemanship. Soc. Anim. 16(2), 107-126.

Christensen J.W., Rundgren M., Olsson K. 2006. Training methods for horses: habituation to a frightening stimulus. Equine Vet. J. 38, 439-443.

Diacont K. 2001. Praca z końmi od podstaw. Warszawa, Oficyna Wydaw. HOŻA. [in Polish]

Dudziak M. 2012. Jedność z koniem. Partnerstwo i sztuka ujeżdżenia. Wrocław, Astrum. [in Polish]

Fedorski J. 2003. Poradnik dla hodowców i miłośników koni. Warszawa, PWRiL. [in Polish]

Fraser A. 2010. The Behaviour and Welfare of the Horse. Wallingford, CABI.

Gohl C. 2001. Rady dziadka masztalerza. Warszawa, Oficyna Wydawnicza MULTICO. [in Polish]

Gołąb J. 2017. Partnerstwo doskonałe. Koński punkt widzenia. Lewin Kłodzki, Wydawnictwo Rancho Stokrotka. [in Polish]

Haller M. 1997. Rasy koni. Warszawa, Oficyna Wydawnicza MULTICO. [in Polish]

Hill C. 2015. Myśleć jak koń. Łódź, Galaktyka. [in Polish]

Hill C. 2016. Co każdy koń wiedzieć powinien. Łódź, Galaktyka. [in Polish]

Jackson J. 2003. Świat koni i naturalnej pielęgnacji koni. Łódź, Galaktyka. [in Polish]

Jodkowska E., Sułek P., Sabok K. 2016. Wstępne badania nad skutecznością treningu koni metodą Join-up w zależności od pory karmienia [A preliminary study on the effectiveness of Join-Up training of horses in relation to the time of feeding]. Prz. Hod. 4, 22-25. [in Polish]

Łojek J., Łojek A. 2015. Człowiek i koń - próba równoważenia interesów [Human and horse - an attempt at balancing interests]. Prz. Filozoficz., Nowa Seria 2(94), 35-49. [in Polish]

Miller R. 2007. Sekrety końskiego umysłu. Łódź, Galaktyka. [in Polish]

Miller R.M., Lamb R. 2005. The revolution in Horsemanship and what it means to Mankind. Guildford, The Lyons Press.

Roberts M. 2004. Ode mnie dla was. Warszawa, Agencja PDM. [in Polish]

Szymczak B. 2004. Chcę mieć własnego konia. Warszawa, Oficyna Wydawnicza MULTICO. [in Polish] Wilczyńska K., Andraszek K., Danielewicz A. 2017. Malopolski horses-sport or recreation? Folia Pomer. Univ. Technol. Stetin., Agric., Aliment., Pisc., Zootech. 332(41)1, 107-116.

Wilk I., Janczarek I. 2014. Naturalne metody treningu jako nowoczesne techniki szkolenia koni w zgodzie z naturą i dobrostanem gatunku [Sympathetic training method as a modern technique of Equus caballus training in harmony with the nature and the welfare of the species]. Med. Weter. 70(2), 94-97. [in Polish] 
Zeitler-Feicht M.H. 2014. Zachowania koni. Przyczyna, terapia i profilaktyka. Warszawa, Świadome Jeździectwo. [in Polish]

Żebrowska J., Danielewicz A., Andraszek K. 2013. Genetyczne uwarunkowania sprawności fizycznej koni [Genetic determinants of the physical fitness of horses]. Prz. Hod. 2, 24-27. [in Polish]

\title{
UŻYTKOWANIE I UTRZYMYWANIE KONI W ASPEKCIE NATURALNYCH METOD TRENINGOWYCH
}

\begin{abstract}
Streszczenie. W wyniku ewolucji ludzkość przeszła z koczowniczego na osiadły tryb życia, od łowiectwa i zbieractwa do produkcji roślinnej i hodowli zwierząt. Spowodowało to zmianę traktowania koni oraz dostrzeżenie ich potrzeb emocjonalnych. Skoncentrowano się na budowaniu relacji z nimi. Obecnie konie są postrzegane jako jedne z najbardziej inteligentnych zwierząt „współpracujących” z ludźmi. W czterech ośrodkach jeździeckich zbadano 62 konie: klacze, ogiery i wałachy, w wieku od 3 do 26 lat, ośmiu ras: czystej krwi arabskiej, małopolskiej, huculskiej, polski koń szlachetny półkrwi, śląskiej, polski koń zimnokrwisty, kuc szetlandzki, haflinger. Trzy ośrodki zajmowały się rekreacją, posiadały do 11 koni - klaczy i wałachów; jedynie drugi ośrodek posiadał ogiera, czwarty ośrodek miał rangę stadniny, dlatego posiadał 22 klacze i 4 ogiery hodowlane. Analizowane formy treningu koni wykazały, iż wszystkie ośrodki w przypadku $100 \%$ swoich koni stosowały klasyczne metody treningowe. Trenerzy deklarowali zainteresowanie metodami naturalnymi, ale jako formę wspomagającą metody klasyczne. Naturalne metody pracy z końmi stosowały ośrodki II i III, w których konie pracowały wierzchowo i rekreacyjnie, jak również sportowo. Nie stosowano tego rodzaju treningu w ośrodku I, w którym prowadzono tylko wierzchową rekreację, oraz w ośrodku IV zajmującym się głównie hodowlą i treningiem koni wyścigowych. Konie w ośrodku III i większość koni w ośrodku II uczestniczyły w Siedmiu Zabawach Parellego, join-up, odczulaniu na nieznane przedmioty; przeprowadzono imprinting źrebiąt. Świadczy to o rosnącym zainteresowaniu metodami naturalnymi osób układających konie, ale bez rezygnacji z klasycznego treningu. Badania zrealizowano w celu poznania podejścia hodowców do form utrzymywania i użytkowania koni, w aspekcie zainteresowania imprintingiem źrebiąt, natural horsemanship, join-up i odczulaniem na nieznane przedmioty.
\end{abstract}

Słowa kluczowe: koń, naturalne metody treningu, imprinting, odczulanie. 
